\title{
Erratum to: Bacteria-responsive microRNAs regulate plant innate immunity by modulating plant hormone networks
}

\author{
Weixiong Zhang $\cdot$ Shang Gao $\cdot$ Xiang Zhou $\cdot$ Padmanabhan Chellappan · \\ Zheng Chen $\cdot$ Xuefeng Zhou $\cdot$ Xiaoming Zhang $\cdot$ Nyssa Fromuth $\cdot$ \\ Gabriela Coutino $\cdot$ Michael Coffey $\cdot$ Hailing Jin
}

Published online: 11 March 2011

(C) Springer Science+Business Media B.V. 2011

Erratum to: Plant Mol Biol (2011) 75:93-105

DOI 10.1007/s11103-010-9710-8

Due to an unfortunate mistake, an incorrect version of Fig. 4 has been used in the above mentioned publication. The internal control of U6 in Fig. 4b was accidentally duplicated from Fig. 4a. The adjusted Fig. 4 with the correct U6 control is published below and should be treated as definitive by the reader.

The online version of the original article can be found under doi:10.1007/s11103-010-9710-8.

W. Zhang $(\bowtie) \cdot X$. Zhou $\cdot$ Z. Chen $\cdot$ X. Zhou

Department of Computer Science and Engineering, Washington University in Saint Louis, Campus Box 1045, Saint Louis, MO 63130, USA

e-mail: weixiong.zhang@wustl.edu

S. Gao - P. Chellappan - X. Zhang - N. Fromuth - G. Coutino · M. Coffey $\cdot$ H. Jin $(\square)$

Department of Plant Pathology and Microbiology,

Center for Plant Cell Biology, Institute for Integrative Genome

Biology, University of California, Riverside, CA 92521, USA

e-mail: hailing.jin@ucr.edu

W. Zhang

Department of Genetics, Washington University School

of Medicine, Campus Box 8232, Saint Louis, MO 63110, USA 
Fig. 4 Small RNA Northern blot verification of some of the differentially expressed miRNAs detected by deep sequencing from the three bacterial pathogen infections and the mock controls at a 6-hpi and b 14-hpi. Similar results were obtained from two biological duplicates. U6 RNA was used as a control for measuring the relative amount of the bands (shown below each panel). Imagequant software version 2.1 was used for relative amount quantification (GE Healthcare Life Sciences)

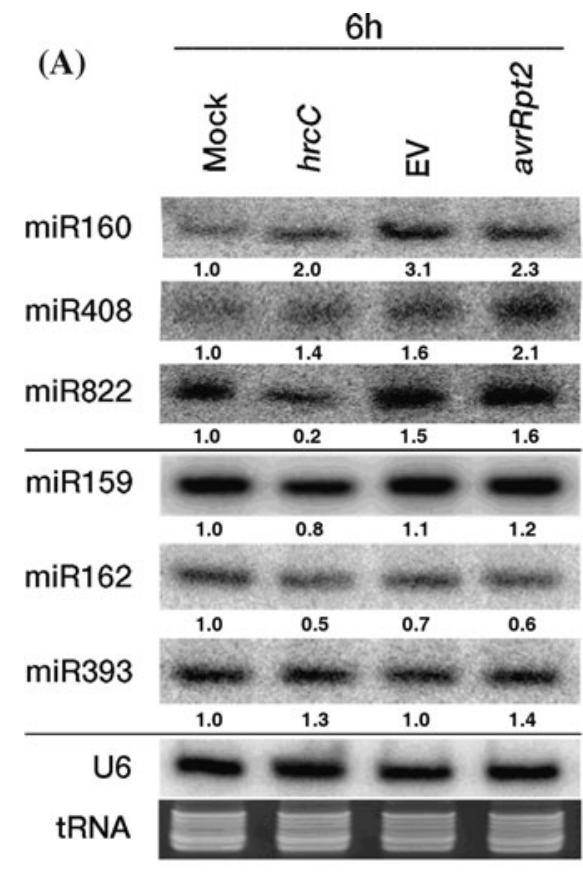

(B) $14 \mathrm{~h}$

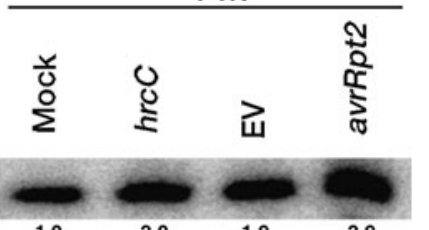

miR158

$\operatorname{miR} 159$

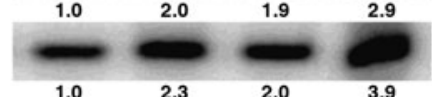

$\operatorname{miR} 166$

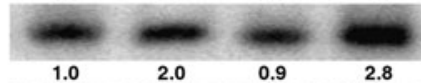

$\operatorname{miR} 393$

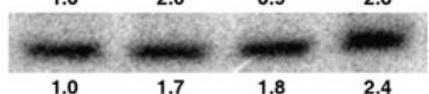

$\operatorname{miR} 408$

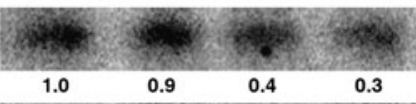

$\operatorname{miR822}$

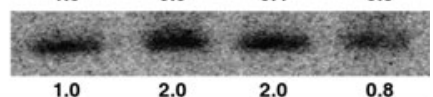

$\operatorname{miR} 852$

miR319

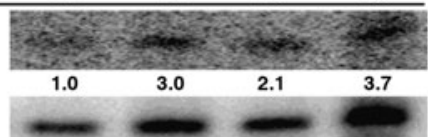

$\begin{array}{llll}1.0 & 2.7 & 2.0 & 3.8\end{array}$

U6

tRNA 